\title{
Farming Intensification and Environmental Justice in Northern Ireland
}

\author{
Ekaterina Gladkova ${ }^{1}$ \\ Published online: 1 February 2020 \\ (c) The Author(s) 2020
}

\begin{abstract}
Going for Growth, an industry-led strategy to expand the agri-food sector, was adopted by the Northern Irish government in 2013 in order to encourage farming intensification in Northern Ireland. This approach, however, threatens an already fragile natural environment and has already had detrimental consequences for human health and well-being. This article employs an environmental justice perspective to scrutinize farming intensification in a community affected by this phenomenon. Based on findings from semi-structured interviews with local residents, the article describes their exposure to environmental risks as a result of farming intensification. The uneven distribution of environmental burdens is also coupled with limited opportunities for the local residents to engage in environmental decision-making and to be recognized as active agents of change. The article concludes that farming intensification in Northern Ireland is marked by procedural environmental injustice and should be addressed by downscaling levels of production and reforming decisionmaking processes.
\end{abstract}

\section{Introduction}

By 2017, Northern Ireland had experienced a sharp rise in the number of intensive pig and poultry farms (those housing at least 40,000 poultry birds, 2000 pigs raised for meat, or 750 breeding pigs) - indeed, the number of farms increased by 68\% from 154 in 2011 to 259 in 2017 (The Bureau of Investigative Journalism 2017). Environmental non-governmental organizations (NGOs) and local campaigners attributed this trend to a broader shift in farming intensification, in addition to the Northern Irish government's adoption of the Going for Growth (GfG) strategy in 2013. Industry-led, the GfG endeavored to expand the agri-food sector with the goal of "growing a sustainable, profitable and integrated Agri-Food supply chain, focused on delivering the needs of the market" (Agri-Food Strategy Board 2013: 11). GfG was premised and adopted based on a controversial idea of a pressing need to increase global food production in light of population growth (Tomlinson 2013). The strategy prioritized the export of produce, aiming to grow sales outside

Ekaterina Gladkova

e.gladkova@northumbria.ac.uk

1 Department of Social Sciences, Northumbria University, Ellison Place,

Newcastle upon Tyne NE1 8ST, UK 
Northern Ireland by 75\% (Agri-Food Strategy Board 2013: 11) and called for governmentled incentives to encourage economies of scale at producer and processor levels. The latter entailed incentivizing "larger, more diversified farm units across Northern Ireland, with lower production costs, higher productivity and higher environmental and welfare standards, enabling the promotion of a stronger, more profitable product" (Montgomery 2015: 8). GfG secured substantial amounts of government and industry investment- $£ 442$ million in 2016 (Agri-Food Strategy Board 2016: 8) — that was channeled, among other things, into creating a strategic marketing body to promote the Northern Irish agri-food brand, developing research into livestock genetics and livestock improvement, and ensuring green, sustainable growth (AFSB001). ${ }^{1}$ Overall, the strategy focused on farming expansion in Northern Ireland, allowing the country's agri-food industry to keep pace with the global trends in meat production governance. To put it in context, the number of intensive farms in the United Kingdom (UK), overall, has risen by a quarter since 2011 (The Bureau of Investigative Journalism 2017). Similarly, the Republic of Ireland has also been experiencing state-sponsored promotion of intensive agricultural expansion (Environmental Pillar 2016).

The farming industry identified the pig sector as holding the potential to be especially successful in Northern Ireland with respect to its ability to meet the demands of the market without relying on government subsidies as a source of income. A comparison of the Agricultural Census in Northern Ireland conducted by the Department of Agriculture, Environment and Rural Affairs (DAERA) in 2000 and 2017 demonstrates the evolution of the pig sector in terms of concentration and intensification: in 2000, 808 pig farms in Northern Ireland had a total of 413,480 pigs (DAERA 2000); in 2017, the number of farms fell to 322, but the number of animals increased to 649,120 (DAERA 2018). Moreover, the 2017 census emphasized that "a small number of large, highly productive businesses drive most of the change in the sector." The GfG strategy provided further impetus for the sector's expansion. Since the adoption of the strategy in 2013, the total number of pigs rose dramatically from 480,317 in 2013 to the above-mentioned 649,120 in 2017 (DAERA 2018). The number of planning applications for new pig farms or pig farm extensions currently appears to be on the rise as well, as more farmers become embedded in the "treadmill of production" (discussed below) and profit maximization (Lynch and Stretesky 2014).

While pig farming intensifies as a response to global capitalist conditions of continued growth and the ambitions of the GfG strategy, the ecological sustainability of this phenomenon is being called into question (Foord 2017). Ammonia emissions, in particular, associated with animal manure and nitrogen fertilizers, have hit crisis levels in Northern Ireland (Northern Ireland Fresh Water Taskforce 2018). Agriculture and farming are the main sources of ammonia emissions (93\% in 2016) (DAERA and NIEA 2018), and Friends of the Earth (2018) has suggested that these ammonia emissions are clustered geographically around areas with high densities of intensive livestock farms. Ammonia emissions from livestock have increased by $7.4 \%$ since 2001 - in comparison with a $2.9 \%$ decrease for the UK as a whole over the same period (DAERA and NIEA 2018). Average per capita ammonia emissions for Northern Ireland are currently exceeded by more than four times that of other parts of the UK (DAERA 2019). Twelve percent of total UK ammonia emissions come from Northern Ireland - a figure that is disproportionate to both Northern Ireland's

\footnotetext{
1 This reference denotes a response by one of the research participants. The coding system for this article will be explained later in the "Methodology" part.
} 
population (3\% of the UK total) and its land area (6\% of the UK total) (Friends of the Earth 2018).

The seriousness of ammonia emissions should not be underestimated. Ammonia is one of the main sources of nitrogen pollution and has an adverse impact on air quality, natural ecosystems, and water bodies. According to DAERA (2019), most of Northern Ireland, including its protected areas, have levels of nitrogen significantly above their "critical load," posing a risk of serious ecological damage. Indeed, critical levels of ammonia from animal manure are exceeded at $90 \%$ of the protected habitats in Northern Ireland (DAERA 2019). Moreover, ammonia emissions also affect the state of water bodies in Northern Ireland. In 2015, just one-third of monitored river water bodies received a "good" standard (or better) and only five out of 21 lakes achieved a "good" standard (DAERA and NIEA 2018), while other water bodies showed signs of nitrogen pollution.

Finally, ammonia emitted from animal manure mixes with other pollutants in the atmosphere, creating small particles also known as particulate matter (PM). PM is associated with human health impacts: it lodges in the lungs and bloodstream (DAERA 2019) and is linked to cardiovascular diseases, cognitive decline, higher death rates, low birth weights, and respiratory problems (The Bureau of Investigative Journalism 2017; Schraufnagel et al. 2019). It has been demonstrated that residents who live within two kilometers of intensive pig farms could be exposed to ammonia levels up to 40 times greater than average ammonia concentrations (Ponette-Gonzalez and Fry 2010). This can result in increased occurrences of headaches, runny nose, and sore throat, as well as burning eyes, excessive coughing, and diarrhea (Wing and Wolf 2000). According to the recent investigation from the Bureau of Investigative Journalism (2019), halving ammonia emissions in the whole of the UK could prevent at least 3000 premature deaths from air pollution per year.

The rising number of intensive pig farms is likely to continue to have serious impacts on human health and to exacerbate further the existing environmental problems in Northern Ireland. Moreover, those living in close proximity to such farms are likely to be exposed to a disproportionate amount of environmental burdens from intensive farming (Donham et al. 2007; Gunderson 2015), in addition to the risks associated with modern industrial systems (Stoddard 2015).

The environmental justice paradigm appears to be a suitable lens for evaluating the impact of pig farming intensification on a rural community in Northern Ireland because it illuminates not only the distribution of environmental benefits and burdens but also the extent of individual and community recognition and participation (Schlosberg 2007) in relation to farming intensification. Previous research that applied the lens of environmental justice to a case of farming intensification analyzed the impacts of corporate pig meat production on farm loss among minority communities (Edwards and Ladd 2000) and linked the environmental justice paradigm with grassroots protest against corporate agriculture (Ladd and Edwards 2002). The innovative contribution of this article is to consider public participation in decision-making regarding this phenomenon. In so doing, it calls attention to the need for more research on procedural environmental justice in green criminology and expands on the insufficiently discussed concept of capabilities in it (Heydon 2018). Moreover, this article forwards the argument that non-marginalized populations can also face environmental injustice, thus expanding existing green criminological research on the topic.

This article begins by introducing the multi-dimensional structure of the concept of environmental justice and proceeds to describe the origins of empirical data used in this article. From here, this article discusses how environmental harms from farming are currently distributed in the studied community and analyzes the structure of environmental 
decision-making that has already contributed to existing maldistribution of harm and that is likely to exacerbate it in the future. The article concludes with a call for not only reforming the environmental decision-making forums in Northern Ireland but, more importantly, for reversing pig farming intensification and changing the dominant mode of production.

\section{Green Criminology and Environmental Justice}

In green criminology, conceptualizations of harm often focus on questions of justice rather than on the legality or illegality of a given act or omission (Larsen 2012; Walters 2013). The environmental justice perspective, linked closely to broader issues of social justice, conceptualizes much environmental crime as environmental classism and racism (Gaarder 2013; Gibbs et al. 2010) and seeks to expose how and the ways in which environmental harms tend to be concentrated in areas with economically marginalized communities. Most analyses of environmental justice tend to overlook the link between the treadmill of capitalist production, ${ }^{2}$ on the one hand, and environmental justice, on the other; green criminological perspective employed in this article is vital for unpacking this link (Lynch et al. 2015).

Discussions of environmental justice have revolved around distributional justice-the distribution of environmental advantages and disadvantages (Lynch 2016), as well as the proximity to polluting facilities (Haughton 1999). More recently, proponents and scholars of environmental justice have considered questions surrounding procedural justice, including individual and community recognition in the decision-making process and political participation. I discuss distributional and procedural justice in turn.

For White (2008:15), distributional justice refers to "the distribution of environments among peoples in terms of access to and use of specific natural resources in defined geographical areas, and the impacts of particular social practices and environmental hazards on specific populations." Environmental justice proponents argue that the deprived and disadvantaged suffer from those harms more than those in positions of power and that their capacity to respond to harm is limited. In addition, environmental justice scholarship is also concerned with the distribution of environmental risk that is created by the treadmill of production and that is deemed to intensify class inequalities (Curran 2016, 2017). This resonates with the notion of "second modernity" or risk society, where side effects of modernization result in the "social production of risks" (Beck 1992).

The vast majority of empirical green criminological research on environmental justice has devoted substantial attention to distributional justice and the topic of unequal access to environmental quality (Lynch and Barrett 2017; Lynch and Stretesky 2012; Stretesky 2003; Stretesky and Lynch 1998, 2002; White 2003, 2008). This line of research is concerned with evening out the distribution of environmental harm by highlighting the processes of victimization experienced by certain groups based on their racial, ethnic, and class background. Many contend, however, that environmental justice cannot be disentangled from other forms of justice (e.g., Schlosberg 2007). As a result, many environmental justice advocates are also concerned with social, cultural, and political processes of environmental decision-making (Chakraborty 2017; Holifield et al. 2018), thereby echoing the call of prominent environmental justice scholars to explain the causes of and dynamics leading to

\footnotetext{
2 The theory of the treadmill of production, rooted in Schnaiberg's (1980) work, posits that capitalist organization of social and economic life brings about ecological disorganization (Lynch and Stretesky 2014).
} 
the inequitable distribution of environmental advantages and disadvantages (Bullard 1993; Fraser 1998; Pulido 1996; Young 1990). This concern has begun to resonate with green criminological scholarship and has invited further engagement with the concept of procedural environmental justice. Indeed, Heydon (2018, in press), for example, whose work is discussed in greater detail below, has drawn on Schlosberg's (2007) multifaceted conception of justice, which theorizes environmental justice as a synthesis of distribution, individual and community recognition, participation, and delivery of basic capabilities.

Much like research on distributional injustice, studies of procedural injustice have examined socially and culturally marginalized groups (Heydon 2018; Holifield 2012). Bustos and colleagues (2017) suggest, however, that explorations of procedural environmental justice should extend beyond marginalized groups and this article continues their line of thinking. If the core of environmental injustice is disenfranchisement, then non-marginal groups can also face environmental injustice if they have limited influence within the decision-making process over the changes in their local environment that are likely to impact their lives. This lack of power may manifest in excluding certain issues or topics on the level of institutional practices, meaning that certain issues do not appear on the agendas of local and national political bodies (Lukes 1974). Moreover, Bustos and colleagues (2017: 297) stress that formal participatory processes of environmental decision-making exclude the views situated outside "the reigning 'consensuses' (in economic, environmental and development terms)," preventing individuals from defending their way of life. The presence of formal participatory processes may be interpreted as an example of the "normal" exercise of the hegemony of neoliberal capitalism, where the decisions affecting the environment appear to be based on the consent of the majority, while in reality, it favors the interests of those benefitting from these decisions (Gramsci 1971).

Generally, procedural environmental justice is conceptualized as fairness in the processes of decision-making-reflecting an understanding of "who has the power to make decisions, the kinds of decisions that are made, in whose interests they are made, and how social practices based on these decisions are materially organized" (White 2008: 56). Procedural environmental justice rests on the pillars of recognition and participation.

Recognition is a relationship (Young 1990), which is deeply embedded both culturally and politically (Walker 2012). It refers to dignity accorded to all despite the differences in ways of living that might exist (Sikor and Newell 2014), and for environmental justice scholarship, it entails the recognition of the diversity of participants from affected communities and recognition of their experiences (Schlosberg 2004). As a result, misrecognition might take forms of domination, complete non-recognition, or disrespect (Fraser 1998) which, in turn, is unjust insofar as it creates a scenario in which individuals are not treated equally (Heydon 2018). Instead, decision-making processes should reflect inclusivity, respectfulness, and equality (Heydon 2018).

While recognition in environmental justice means acknowledging different experiences of living with and in the natural environment, participation refers to the manner in which these different experiences are validated (Schlosberg 2004). Participation means wider engagement combined with democratic decision-making (White 2014), and it has its roots in research on public participation (Arnstein 1969), whereby participation equals power (Arnstein 1969). For a procedure to be just, participants should be provided with an opportunity to listen and be heard, sufficient notice of that opportunity, occasions for the provision of input in decisions that are likely to affect their environment, and they should have their input respected and taken into consideration during decision-making (George and Reed 2017). Brisman (2013) suggests that restrictions of participation contribute to cultures of silence that extinguish willingness and compromise the ability to contest 
environmental harm and environmental injustice, while Heydon (in press) concludes that unequal distribution of environmental harms may result from unequal participation in decision-making processes, which in turn might stem from the lack of recognition.

Before turning to a discussion of methodology, it is necessary to note the role of capabilities in conceptualizations of environmental justice. White (2014: 90) employs the word capabilities to mean that "each thing should be able to flourish as the thing it is," and he refers to a range of conditions and instrumental needs vital for maintaining one's life. Capabilities encompasses individual agency and well-being, and the measure of justice thus depends on whether the existing capabilities and the ability to exercise them allow for a fully functioning life (Schlosberg 2007). The environment can be seen as the main producer of capabilities (Nussbaum 1997; Sen 1999). Environmental circumstances and the ability to flourish are intertwined, and exposure to environmental harm negatively affects "a range of rights and capabilities necessary for our functioning, and so it creates injustice" (Schlosberg 2014: 78). In addition, control over one's environment is also a capability necessary for human flourishing and should be delivered by governments through the right of political participation premised on the notion of respect (Nussbaum 1997). Injustice in relation to the capabilities component of procedural justice occurs when this right is limited (Schlosberg 2007). The notion of capabilities, thus, links distributional and procedural components of environmental justice, while considering a broader set of conditions necessary for a full human functioning (Schlosberg 2007).

To summarize, then, the theoretical foundation for this article is informed by the green criminological perspective and, more specifically, the environmental justice paradigm, with a particular focus on procedural environmental injustice. This article considers the distribution of environmental and social burdens from farming intensification and how this phenomenon may affect the delivery of capabilities. The chosen theoretical foundation also helps to analyze the decision-making behind farming intensification through the notions of recognition and participation.

\section{Methodology}

This article utilized a case study research design, and its empirical basis originated from semi-structured interviews with the residents affected by farming intensification in the Newtownabbey area in County Antrim north of Belfast in Northern Ireland. Alkon and colleagues (2013) claim that obtaining insights into community perspectives is essential for providing support for those affected by environmental inequalities. I selected this area because several planning applications for intensive farms had been submitted to the local planning authorities and the area already had a large pig farm that houses approximately 9000 animals, as well as a number of smaller farms. As a result, it presented a suitable location for scrutinizing both the distribution of environmental burdens of farming intensification and the structures that underpinned decision-making behind it.

In addition to the choice of location, the selection of participants for this research was a crucial part of the general sampling process (Bryman 2012). Snowball sampling was employed: the key informants from the area provided information on farming intensification in the area, and other potential informants were identified in due course. The key informants were selected based on the following criteria: they had available knowledge 
and/or experience needed for this research; they were capable of reflection; they had time to be interviewed; and they were willing to take part in this research (Flick 2014).

I interviewed fifteen individuals in person in November and December 2018. I conducted eight interviews with non-farmer residents-both those who actively oppose largescale farm projects in the area and those neutral about such projects (codified as COM in this article). I also interviewed three local NGO workers and four local government officials: two local councilors (codified as $\mathrm{COU}$ in this paper) and two local Members of the Legislative Assembly (MLAs). The participants interviewed were "the 'right persons' to study in terms of the "theory" (Brannen 2012: 16) in that out of the total possible number of resident participants, they were the ones affected directly by the existing farms and/or the ones who participated in the decision-making processes behind farming intensification. Government officials interviewed in the course of this research were involved directly in decision-making regarding farming intensification. The small sample of local government officials was due to the challenges of interviewing "elites" (Welch et al. 2002), such as access to participants. To mitigate this challenge, I assumed the role of an informed outsider (Welch et al. 2002). I also emphasized my researcher status when participants were contacted and presented my university affiliation as a beneficial factor to appear more impartial.

During the interviews, the resident participants were asked about their views on the impact of pig farming intensification, on the natural environment and cultural identity of the area, on their participation in the decision-making process around new farm developments, and about the recognition of their views in that process. Local government officials, on the other hand, were asked about the planning process in Northern Ireland and their engagement with residents on the matters related to farming intensification. Each interview lasted from forty-five minutes to two hours. The technique employed for the analysis of the qualitative data in this research entailed following the steps proposed by Braun and Clarke (2006): familiarizing myself with the data, generating initial codes, searching for themes, reviewing themes, defining and naming themes, producing the report. ${ }^{3}$

\section{Distributional Environmental Injustice and Farming Intensification}

As stated above, farming intensification poses a risk to ecological systems and jeopardizes air and water quality, all of which were a concern to participants. Newtownabbey residents were preoccupied with and displeased about the proliferation of intensive farms in the area. As one interviewee put it, "You can't put too much in one place. If you put too much farming in one place, you get pollution. It's like giving the land its heart attack, you're destroying the ecological balance" (COM002).

The disposal of animal waste presented a challenge for the area. Whereas for non-intensive farms, animal waste is an essential element of a natural nutrient cycle, for intensive farms, animal waste disposal becomes a problem (Goodman and Redclift 1991; Gray and Hinch 2015). Mismanagement of waste, itself, and wastewater results in air, soil, and water

\footnotetext{
3 In terms of ethics, I adhered to the principle of informed consent during interviews. Before the start of each interview, I presented an information sheet to the participants, which explained the nature of the research, the interview procedure, the benefits and disadvantages of participating, personal data-related issues, and their rights as participants. In addition, I asked participants to sign a consent form. I also adhered to the principle of confidentiality because personal details of all participants were codified.
} 
pollution. A common current practice is to spray fields with liquid manure, yet the proliferation of farms means that the amount of animal waste will increase dramatically: "I think [pig farming expansion] is a very bad idea. The worst thing is the amount of nitrates and slurry that will be produced and dumped on the land" (COM007). Yet, the present practices of animal waste disposal are already having an impact in the area.

Water pollution was a particular concern for the Newtownabbey residents, both in terms of its impact on the native species and on the local people (COM001; COM002; COM007). Water pollution stems from the fact that "generally accepted livestock waste management practices do not adequately or effectively protect water resources from contamination" (Burkholder et al. 2007: 308). Already, water contamination has taken place in the area: "There have been episodes of water pollution from the existing farm and the farmer has been convicted in court" (COM002), and the respondents expressed their uncertainty about the future of local water quality. Moreover, for the local residents, water pollution was also associated with risk: "There was also a wastewater leak going into the river. From my point of view, ... dogs that I walk there-I don't want them to be on land or let alone swim somewhere where there's a risk. And I wouldn't know if there's a risk, it's not something that you can see per se" (COM001). The production of risk from water pollution is linked to the rise in intensive farms in Newtownabbey area, but at the same time, it is part of the collective production of environmental risk from farming intensification in Northern Ireland and elsewhere (Curran 2016). Ultimately, risk becomes an inevitable part of the neoliberal governance of meat production (Stoddard 2015). The prioritization of the economic growth in neoliberal capitalism is accompanied by the creation of manufactured risks, which, in the context of meat production, have an impact on the environment and human health. Without such risks, however, economic growth becomes impossible. Moreover, there is uncertainty associated with risk, which impedes planning for the future. In Newtownabbey, the risks of expanding production create ambiguity around addressing the impacts of them in the long term: "Then there's an environmental impact that this concentration of animals will cause - a considerable amount of waste that will be produced and how it will be disposed of. There are a lot of issues that aren't well understood and how we can deal with them in the future" (COU001). The distribution of environmental risks (Curran 2018) from water pollution is uneven insofar as the residents living in close proximity to existing farms are exposed to a higher amount of risk, and the proliferation of farms in the area is likely to exacerbate it.

The respondents also saw the existing farms as a burden on the local ecological system and were concerned about the loss of biodiversity: "If you look at what's happening to the countryside, it's becoming sterile. Those used to be fields with different grasses and wildflowers, there was an orchard. What was the first thing they [the farmers] did? They fenced it to keep out larger animals - foxes, badgers. Then they plowed it and put in a particular grass that will produce silage for them" (COM006). According to Wyatt (2014), intensive farming may foment deforestation and loss of vegetation, and it also has adverse effects on wildlife. Indeed, as was noted above, ammonia emissions from animal waste are undermining the diversity of local ecological systems: "The house down the field has a meadow next to it and all wildlife disappeared from there. When we first moved here, the neighboring pig farm had land and other animals on it. And then it was bought over-they sold off all the land and just kept the pig farms, so it was transformed from a family farm into a pig factory" (COM007).

While the challenges linked to air pollution in the form of ammonia have been outlined above, the studied area is likely to face a higher concentration of ammonia as pig farming intensification gathers pace: "environmentally, we have a collective of pig farms 
which will happen in this area. As you know, ammonia levels are up through the roof" (COU002). Indeed, the burden of air pollution serves as an intersection of environmental and social harm. Dybing (2012) claims that environmental harm is social harm because ecological processes are incorporated into social life. Moreover, air and water pollution and soil degradation contribute to mental and physical health risks, thus rupturing "the organic reproduction of "man" (Lasslett 2010:12). There is evidence to suggest that communities in close proximity to intensive farms and fields where the slurry is spread are exposed to antibiotic-resistant bacteria and have higher risks of developing respiratory diseases, Q fever, and change in stress and mood levels (Casey et al. 2015). This concern was reflected in the interviews: "they spread slurry in a field not too far from a nursery school. Nobody could tell those kids what they're breathing" (COM004).

The high concentration of environmental burdens from existing pig farms in the area is affecting the community's quality of life: "everywhere they are spreading the slurry, the fields are surrounded by villages. It will have an effect on the health of the people and their quality of life" (COM007). As noted above, capabilities represent possibilities to enjoy one's natural environment (Sen 1999); that possibility is already compromised and will be further forfeited if farming intensification continues. For instance, a capability of breathing unpolluted air is corroded by the smell from existing farms and slurry spreading, which was highlighted by all respondents: "I had been living close to the existing farm before I moved, the smell is horrendous" (COM003).

Furthermore, the experiences of "the unequal access to healthy sensory environments" (Hoover 2018), whereby the community has a limited opportunity to enjoy good-quality air, are intertwined with a limited ability to both access and enjoy the outdoor environment. As one interviewee explained:

A pig farm just across the road from us with 4300 pigs had an impact on us and it'll be multiplied once those [big] farms are built. The existing unit will also be expanded and the number of pigs will increase dramatically. It impacts all aspects of your life-we don't have a clothesline outside, we can't open the windows and doors at times, we can't use our garden in the summertime because of the smell and flies. [COM007]

Similarly, another stated: "If the new planning application goes through, we'll end up with three intensive farms in a very small area. Nobody would want to go to the countryside when it's up and running" (COM004).

These quotations offer evidence that the disproportionate amount of environmental burdens from farming currently has an impact on people's well-being in the area. Moreover, the responses describe the local area as rural - an underexplored dimension of study in research on environmental justice is the relationship between (and within) urban and rural areas (Jones 2011). In the case of farming intensification, rural environmental injustice is perpetuated through urban-rural exploitation, where the main beneficiaries of intensification might not live in the rural areas that experience harm, while rural populations are harmed by pollution from the production practices that benefit proportionally more urban people (Kelly-Reif and Wing 2016).

To continue the discussion of capabilities, it is important to recall that Nussbaum (2001) includes control over one's environment in her basic set of capabilities. The local residents that I interviewed do not possess this capability, which has a subsequent negative effect on community functioning (Schlosberg 2014). As one resident described, "[the new farm] is a blight on the natural environment-it's concerning whether the environment is safe now, 
whether the water is safe, how long it's going to be safe for. It does take away some enjoyment from being outside—-knowing that it's been polluted and destroyed" (COM003).

The lack of control over one's environment is also exemplified by the local community's position on the decision-making forum regarding farming intensification in the area. The local ecosystem can be seen as reflecting political power and cultural meaning (Haraway 1997; Swyngedouw 2001), and in the case of Northern Ireland, it is being reconfigured to serve dominant economic interests of farming intensification (Castree 2001). This reconfiguration exacerbates the unequal exposure to environmental harms produced by the capitalist organization of meat production (Lynch 2016), and the possibilities afforded to individuals and communities to prevent such harms are limited (Walker and Bulkeley 2006). The latter will be discussed in the next part.

\section{Procedural Environmental Injustice and Farming Intensification}

Procedural environmental justice pivots on the "fairness" of the processes through which the distribution of environmental benefits and burdens occurs (Walker and Bulkeley 2006). Before discussing procedural environmental justice in the context of the Newtownabbey area in County Antrim, it is necessary to describe the opportunities for individuals and communities that exist within the planning framework in Northern Ireland to contribute to the decision-making regarding the construction of new farms.

Planning has a major role to play in delivering sustainable development as it helps ensure that development achieves economic, environmental, and social goals (Friends of the Earth 2006). The 2011 Planning Act in Northern Ireland stresses the importance of engaging communities in the planning system. Community engagement is encapsulated in the Statement of Community Involvement (Planning Act (Northern Ireland) 2011), which provides that "engaging communities is an essential part of good spatial planning and for an effective and inclusive planning system overall" (Department of the Environment 2016). Local councils are expected to involve the community when preparing local development plans. Pursuant to the Statement of Community Involvement, local individuals can inter alia make comments on planning applications, participate in the preparation of development plans and other policy documents, and report breaches of planning control (nidirect n.d.). For major developments (such as intensive farms), early-stage community involvement is organized through pre-application community consultation. A community consultation process should ensure that people have access to information about a prospective development and "have an active role in developing proposals and options to ensure local knowledge and perspectives are taken into account" (Department of the Environment 2014: 2). Applicants for major development projects are also advised to engage with the local community and environmental groups, individual residents, businesses in the vicinity of the site, and other relevant stakeholders (Department of the Environment 2014).

The comments made by the community form the basis of the Pre-Application Community Consultation Report, where applicants for major development projects describe in detail how they responded to the comments made by the community, including changes and mitigation measures to address community concerns. In addition, the council engages with residents occupying buildings on land adjoining the application site boundary, as well as with residents within 90 meters of the application site (Department of the Environment 2016). Such residents can respond to neighbor notifications within fourteen days. Community members interested in a planning application and the 
supporting documents behind it can view them online on the Planning Portal. The Planning Portal allows anyone to comment on a planning application or object to the planning development, and the Statement of Community Involvement guarantees that "all comments will be fully considered" (Department of the Environment 2016: 9). After the council makes its decision, community members cannot file an appeal. In Northern Ireland, only applicants have the right to appeal a refusal of planning permission or to challenge conditions which have been imposed on an accepted application. There is no "third party" right of appeal that allows community members to challenge a planning decision (Friends of the Earth 2006; Northern Ireland Assembly 2016). In theory, local individuals and communities are provided with a forum for influencing the decisionmaking processes that affect their lives. In practice, however, the absence of the "third party" right of appeal shifts the balance of power in favor of economic rather than environmental and social sustainability, with community involvement being marred by compromised participation and a lack of recognition of community views.

As discussed above, for an environmental decision-making procedure to be just, participants' perspectives and views need to be recognized; they should be given an opportunity for the provision of input toward decisions that are likely to affect their environment and to have that input respected and taken into consideration in decision-making process (George and Reed 2017; Heydon 2018). My research revealed that the ideas categorized by the opposition to farming intensification in the area were largely ignored. Residents pointed out that the decision-making process did not take seriously their environmental concerns (COM002; COM004; COM005; COM006): "I don't think [the council] recognizes the views and concerns of people-they just let everything happen.... I know there were a lot of people pushing hard to form an opposition, but it's been ignored. So I don't know what it would take to get the planners to listen" (COM003). Ignoring stakeholders' views constitutes a form of disrespect (Fraser 1998): "Were the concerns taken into account? They weren't. Even when I went down the line of planning, it was still not believed and ridiculed" (COU002). While individuals, themselves, were allowed to provide input about their concerns, the process of public participation was nevertheless characterized by a lack of recognition of values and lifestyles of those opposing the development (Bustos et al. 2017). Individuals' ideas of how farming should be organized in the area and what environment they would like to live in were not recognized by decision-makers (George and Reed 2017). The latter is the first marker of recognitional injustice (Hunold and Young 1998). In this case, injustice is based on non-recognition of the ideas that contradict the dominant mode of meat production.

Another marker of recognitional injustice is the non-recognition of individuals-specifically, of non-expert voices in the decision-making process (Walker 2012). The respondents complained that "the only letters they [the council] paid any attention to were the letters that came from expert engineers. They paid attention to that because it came from experts. Another one was from an MBA in planning because they saw a specialist planner. This whole idea that local people will be listened to-nobody paid any attention at all" (COM006). Thus, local residents' views were dismissed because of the perception of their lack of expertise, which is another example of recognitional injustice. The question of who has the right to make what decisions is a question of justice (Hunold and Young 1998) and in this case, decision-making was not inclusive without non-experts participating as equals. Moreover, even when some of the local residents acquired technical and legal insights into the planning process (Hunold and Young 1998) and became "unofficial regulators," revealing the administrative errors in the planning system, their valid complaints were still disregarded: "How do you persuade the council that they've told lies? It's too late, they passed 
it. And that's the whole problem-you spend an awful amount of time fighting it and they aren't really listening" (COM002).

This lack of recognition of both community values and lifestyles, as well as non-expert voices, compromises meaningful participation. Local residents were included formally in the decision-making process and could provide input by commenting on the farm planning application and engaging with the local council. The input they provided, however, was not taken into consideration in the final determinations (George and Reed 2017): "We had a meeting with a head planner and he encouraged us to write to the planners and let our views be known because they were interested in listening to the views and expertise and local knowledge that [we] would have. But it was all ignored! The letters that I wroteI put information about different mistakes, mistakes in the drainage, different aspects of it, nobody paid any attention" (COM006). Thus, local residents were heard, but did not possess the power to guarantee that the decision-makers would heed their input (Arnstein 1969). They were unable to influence farm construction decisions through official channels, which resulted in their disempowerment in the decision-making process (Bustos et al. 2017).

Community participation was also reduced to "an empty ritual" (Arnstein 1969) and a box-ticking endeavor: "Whenever we went to a predetermination meeting, it was a matter of going through the hoops of a meeting so that they could say that local people have participated. But we didn't! We were each given 3 min to speak. At the planning meeting itself, again there was a very limited input time, but we came first which meant that the applicant was able to respond and rubbish any comments we had. But you never get an opportunity to question what they have to say" (COM006). The last sentence, in particular, illustrates a skewed balance of power, which, according to Arnstein (1969), allows the decision-makers to acknowledge community participation, but without the community benefiting from that participation. Participation without the accompanying empowerment of citizens and the redistribution of power can constitute procedural injustice (George and Reed 2017).

The lack of citizen empowerment can also be scrutinized through the lens of capabilities in procedural justice, described above. If decision-makers work on improving relations between those taking part in decision-making and promote collaborative learning to ultimately guarantee that governing organizations "are 'owned' by the community and other stakeholders" (George and Reed 2017:162), community stakeholders will have greater control over their environment. Unfortunately, and as the local respondents' revealed, the idea of creating infrastructures for democratic participation does not find acceptance in Northern Ireland: "rather than a central authority dictating what the plan should be, councils are devising their plans with community involvement. That's the aspiration, but the culture of treating the public as if they were a nuisance persists. They pay lip service to democratization" (NGO003). Essentially, building individuals' capabilities for participation in environmental decision-making has not been realized in Northern Ireland.

The subject of disempowerment present in the environmental decision-making concerning farming intensification was also reflected in another comment: "As a member of the public you think-they are getting [what they want] but I as a member of the public wouldn't even be heard. It just seems to be that one rule for a corporate is a different rule for an individual" (COM008). In the process of "getting heard," local residents have to engage with the council and, in some cases, the government agencies involved in the decision-making around pig farm planning applications. These bodies possess institutional privilege, and their power manifests itself through patterns of organizational interaction (Smith 1990). Yet, Lukes (1974) suggests that power can be exercised through unseen 
mechanisms; institutional bodies in Northern Ireland are influenced by ideological power exercised by those shaping agri-food policy. The respondents, however, recognized these ideological dimensions of power: "If there is a government policy which is the Going for Growth, why should we stand in the way of growth? It's absolutely ridiculous. The Going for Growth was produced by the big industry, companies that were set to benefit from it. It wasn't to do with the local community...." (COM006). GfG, driven by dominant capitalist ideology, consolidates the importance of the agri-food industry and therefore influences which interests will be protected by the institutional bodies. This presents an example of how the dominant economic interests are protected through consensus rather than coercion (Gramsci 1971).

Another key dimension of power is the ability to shape the choices of those in less powerful positions (Lukes 1974). The local government and the national government agencies protect the dominant ideology by blocking the access of groups that challenge it (Smith 1990). This fuels recognitional injustice - in the form of non-recognition of the values and lifestyles that oppose farming intensification and in the sense of not granting sufficient consideration to the perspectives of individuals without expertise in planning - and procedural injustice - as participation in environmental decision-making lacks meaning as the balance of power is skewed. The present decision-making system reproduced by the institutional bodies is designed "to safeguard the reigning 'consensuses"” (Bustos et al. 2017: 297), which, in the case of Northern Irish agricultural development, are to increase meat production through intensification. The architecture of this planning system ensures these ambitions are safeguarded. For instance, the decision-makers in the local council "have no role or ability to look at ethical issues or any other kind of issues - animal welfare, issues beyond the planning scope' and 'can't ask for expert advice on health, animal health, waste management" (COU001). Consequently, the decision-making system "operates with the logic of exclusion and, in doing so, commits an injustice against those people located outside of the "consensus"' (Bustos et al. 2017: 297) — in this case, the community opposing a planning decision for an intensive farm.

Taken alongside the uneven distribution of environmental burdens, farming intensification in Northern Ireland possesses the markers of recognitional and procedural environmental injustice. The views of local residents on how farming should occur in the area and the environment they wish to live in are not recognized and their non-expert voices are excluded from the decision-making forums. In terms of procedural environmental injustice, local residents' formal participation in the decision-making does not result in the redistribution of power needed to challenge the dominant logic of farming intensification.

\section{Conclusion}

The environmental justice paradigm employed in this article demonstrates how an already disproportionate exposure of some rural communities to environmental harms from farming may be amplified in the future as more farms are built in the process of farming intensification legitimized by the GfG agri-food strategy in Northern Ireland. The distribution of environmental harms is a product of the political-economic organization of capitalism (Lynch 2016). Moreover, this process is marked by recognitional and procedural environmental injustice, where the inability of local communities to "counter-argue the prevailing consensuses that sustain their situation" (Bustos et al. 2017: 292) fuels farming intensification even further. The prevailing consensus in the political economy of capitalism 
prioritizes the economic benefits from farming intensification over the social interests of affected communities, as well as the integrity of local ecological systems.

It is evident that the current direction of the agri-food industry in Northern Ireland is far from sustainable and needs to be challenged. First, decision-making forums need to be reformed to address recognitional and procedural environmental injustice. Not only should the balance of power be shifted in favor of individuals and communities to guarantee participatory parity (Fraser 1998) to recognize views outside the existing political-economic consensus, but the reform of decision-making forums should also enable individuals and communities to decide which environmental problems are produced in the first place (Lake 1996). Such decisions depend on challenging the dominant mode of meat production to transform the "not in my backyard" argument into "not in anyone's backyard" (Faber 2008: 252) and re-orient profit-driven farming toward the concerns of environmental and social sustainability.

Open Access This article is licensed under a Creative Commons Attribution 4.0 International License, which permits use, sharing, adaptation, distribution and reproduction in any medium or format, as long as you give appropriate credit to the original author(s) and the source, provide a link to the Creative Commons licence, and indicate if changes were made. The images or other third party material in this article are included in the article's Creative Commons licence, unless indicated otherwise in a credit line to the material. If material is not included in the article's Creative Commons licence and your intended use is not permitted by statutory regulation or exceeds the permitted use, you will need to obtain permission directly from the copyright holder. To view a copy of this licence, visit http://creativecommons.org/licenses/by/4.0/.

\section{References}

Agri-Food Strategy Board. (2013). Going for growth: A strategic action plan in support of the Northern Ireland agri-food industry. Belfast. https:/www.daera-ni.gov.uk/sites/default/files/publications/dard/ going-for-growth.pdf.

Agri-Food Strategy Board. (2016). Delivering growth: An update on actions to support the NI agri-food industry. Belfast. https://www.daera-ni.gov.uk/sites/default/files/publications/dard/delivering-growt h-progress-report-march-2016.pdf.

Alkon, A., Cortez, M., \& Sze, J. (2013). What is in a name? Language, framing and environmental justice activism in California's central valley. Local Environment, 18(10), 1167-1183.

Arnstein, S. (1969). A ladder of citizen participation. Journal of the American Planning Association, 35(4), $216-224$.

Beck, U. (1992). Risk society: Towards a new modernity. London: SAGE Publications.

Brannen, J. (2012). Expert voices. In S. E. Baker \& R. Edwards (Eds.), How many qualitative interviews is enough. National Centre for Research Methods Review Discussion Paper (pp. 16-17). Available at http://eprints.ncrm.ac.uk/2273.

Braun, V., \& Clarke, V. (2006). Using thematic analysis in psychology. Qualitative Research in Psychology, 3(2), 77-101. https://doi.org/10.1191/1478088706qp063oa.

Brisman, A. (2013). The violence of silence: Some reflections on access to information, public participation in decision-making, and access to justice in matters concerning the environment. Crime, Law and Social Change, 59(3), 291-303.

Bryman, A. (2012). Social research methods (4th ed.). Oxford: Oxford University Press.

Bullard, R. (1993). Confronting environmental racism: Voices from the grassroots. Boston: South End Press.

Burkholder, J., Libra, B., Weyer, P., Heathcote, S., Kolpin, D., Thorne, P., et al. (2007). Impacts of waste from concentrated animal feeding operations on water quality. Environmental Health Perspectives, 115(2), 308-312.

Bustos, B., Folchi, M., \& Fragkou, M. (2017). Coal mining on pastureland in Southern Chile; challenging recognition and participation as guarantees for environmental justice. Geoforum, 84, 292-304. 
Casey, J. A., Kim, B. F., Larsen, J., Price, L. B., \& Nachman, K. E. (2015). Industrial food animal production and community health. Current Environmental Health Report, 2(3), 259-271. https://doi. org/10.1007/s40572-015-0061-0.

Castree, N. (2001). Socializing nature: Theory, practice and politics. In N. Castree \& B. Braun (Eds.), Social nature (pp. 1-21). Oxford: Blackwell.

Chakraborty, J. (2017). Focus on environmental justice: New directions in international research. Environmental Research Letters, 12(3), 1-4.

Curran, D. (2016). Risk, power, and inequality in the 21st century. Basingstoke, Hampshire, UK: Palgrave Macmillan.

Curran, D. (2017). The treadmill of production and the positional economy of consumption. Canadian Review of Sociology, 54(1), 28-47.

Curran, D. (2018). Environmental justice meets risk class: The relational distribution of environmental bads. Antipode, 50(2), 298-318.

DAERA. (2000). The agricultural census in Northern Ireland: Results for June 2000. Belfast. https://www. daera-ni.gov.uk/sites/default/files/publications/dard/census-2000.pdf.

DAERA. (2018). The agricultural census in Northern Ireland: Results for June 2017. Belfast. https://www. daera-ni.gov.uk/sites/default/files/publications/daera/Agricultural\%20Census\%20in\%20Northern \%20Ireland\%202017_0.pdf.

DAERA. (2019). Ammonia emissions in Northern Ireland. Retrieved March 6, 2019, from https://www. daera-ni.gov.uk/articles/ammonia-emissions-northern-ireland.

DAERA \& NIEA. (2018). Northern Ireland environmental statistics Report. Belfast. https://www.daera-ni. gov.uk/sites/default/files/publications/daera/ni-environmental-statistics-report-2018_1.pdf.

Department of the Environment. (2014). Information leaflet 16. Pre-application community consultation guidance. Belfast. https://www.planningni.gov.uk/index/advice/advice_leaflets/pre-applicationcomm unityconsultationguidance-june2014.pdf.

Department of the Environment. (2016). Statement of community involvement (SCI). Belfast. https://www. planningni.gov.uk/index/policy/doeplanningsci30thmarch2016-3.pdf.

Donham, K. J., Wing, S., Osterberg, D., Flora, J. L., Hodne, C., Thu, K. M., \& Thorne, P. S. (2007). Community health and socioeconomic issues surrounding concentrated animal feeding operations. Environmental Health Perspectives, 115(2), 317-320. https://doi.org/10.1289/ehp.8836.

Dybing, S. S. (2012). Environmental harm: social causes and shifting legislative dynamics. In R. Ellefsen, R. Sollund, \& G. Larsen (Eds.), Eco-global crimes: Contemporary problems and future challenges (pp. 273-294). Surrey, UK: Ashgate Publishing Limited.

Edwards, B., \& Ladd, A. (2000). Environmental justice, swine production and farm loss in North Carolina. Sociological Spectrum, 20(3), 263-290. https://doi.org/10.1080/027321700405054.

Environmental Pillar. (2016). Not so green: Debunking the myths around irish agriculture. Available at https ://environmentalpillar.ie/not-so-green-debunking-the-myths-around-irish-agriculture/.

Faber, D. (2008). Capitalizing on environmental injustice. Lanham, MD: Rowman \& Littlefield Publishers Inc.

Flick, U. (2014). The SAGE handbook of qualitative data analysis. Thousand Oaks, CA: SAGE.

Foord, W. (2017). Scenario planning methodology and the politics of food in interesting times-A northern Ireland case study. Glasgow.

Fraser, N. (1998). Social justice in the age of identity politics: Redistribution, recognition, and participation. WZB Discussion Paper, Wissenschaftszentrum Berlin für Sozialforschung (WZB) (pp. 98-108). Berlin.

Friends of the Earth. (2006). Planning for the environment in northern Ireland. London.

Friends of the Earth. (2018). Submission to the environmental audit committee's nitrates inquiry. Belfast.

Gaarder, E. (2013). Evading responsibility for green harm. State-corporate exploitation of race, class and gender inequality. In N. South \& A. Brisman (Eds.), Routledge international handbook of green criminology (pp. 272-281). Abingdon, Oxon, UK: Routledge.

George, C., \& Reed, M. (2017). Revealing inadvertent elitism in stakeholder models of environmental governance: Assessing procedural justice in sustainability organisations. Journal of Environmental Planning and Management, 60(1), 158-177.

Gibbs, C., Gore, M., Mcgarrell, E., \& Rivers, L. (2010). Introducing conservation criminology. The British Journal of Criminology, 50(1), 124-144.

Goodman, D., \& Redclift, M. (1991). Refashioning nature. London: Routledge.

Gramsci, A. (1971). Selections from the prison notebooks (Edited by Q. Hoare \& G. Nowell Smith Trans.). New York: International Publishers.

Gray, A., \& Hinch, R. (2015). Agribusiness, governments and food crime: A critical perspective. In R. Sollund (Ed.), Green harms and crimes: Critical criminology in a changing world (pp. 97-116). London: Palgrave Macmillan UK. 
Gunderson, R. (2015). Meat and inequality. Environmental health consequences of livestock agribusiness. In J. Emel \& H. Neo (Eds.), Political ecologies of meat (pp. 54-58). London: Routledge.

Haraway, D. (1997). Modest_Witness@Second_Millennium.FemaleMan_Meets_OncoMouse: Feminism and technoscience. London: Routledge.

Haughton, G. (1999). Environmental justice and the sustainable city. Journal of Planning, Education and Research, 18(3), 233.

Heydon, J. (2018). Sensitising green criminology to procedural environmental justice: A case study of first nation consultation in the Canadian oil sands. International Journal for Crime, 7(4), 67-82.

Heydon, J. (in press). Procedural environmental injustice in 'Europe's Greenest City': A case study into the felling of Sheffield's street trees. Social Sciences.

Holifield, R. (2012). Environmental justice as recognition and participation in risk assessment: Negotiating and translating health risk at a superfund site in Indian country. Annals of the Association of American Geographers, 102(3), 591-613.

Holifield, R., Walker, G., \& Chakraborty, J. (Eds.). (2018). The Routledge handbook of environmental justice. New York: Routledge.

Hoover, K. (2018). Sensory disruption in modern living and the emergence of sensory inequities. Yale Journal of Biology and Medicine, 91(1), 53-62.

Hunold, C., \& Young, I. (1998). Justice, democracy, and hazardous siting. Political Studies, 46(1), 82-95.

Jones, C. (2011). Environmental justice in rural context: Land-application of biosolids in central Virginia. Environmental Justice, 4(1), 1-15.

Kelly-Reif, K., \& Wing, S. (2016). Urban-rural exploitation: An underappreciated dimension of environmental injustice. Journal of Rural Studies, 47(A), 350-358.

Ladd, A., \& Edwards, B. (2002). Corporate swine and capitalist pigs: A decade of environmental injustice and protest in North Carolina. Social Justice, 29(3), 26-46.

Lake, R. (1996). Volunteers, NIMBYs, and environmental justice: Dilemmas of democratic practice. Antipode, 28(2), 160-174.

Larsen, G. (2012). The most serious crime: Eco-genocide concepts and perspectives in eco-global criminology. In R. Ellefsen, R. Sollund, \& G. Larsen (Eds.), Eco-global crimes: Contemporary problems and future challenges (pp. 33-57). Surrey, UK: Ashgate Publishing Limited.

Lasslett, K. (2010). Crime or social harm? A dialectical perspective. Crime, Law and Social Change, 54(1), $1-19$.

Lukes, S. (1974). Power: A radical view. London: Macmillan.

Lynch, M. (2016). The ecological distribution of community advantage and disadvantage: Power structures, political economy, communities, and green-state crime and justice. Critical Criminology: An International Journal, 24(3), 247-262.

Lynch, M., \& Barrett, K. (2017). Environmental crime and justice: A green criminological examination. In R. Holifield, G. Walker, \& J. Chakraborty (Eds.), The Routledge handbook of environmental justice (pp. 425436). New York: Routledge.

Lynch, M., \& Stretesky, P. (2012). Native Americans and social and environmental justice: Implications for criminology. Social Justice, 38(3), 104-124.

Lynch, M., \& Stretesky, P. (2014). Exploring green criminology: Toward a green criminological revolution. London: Ashgate Publishing Limited.

Lynch M., Stretesky P., \& Long M. (2015). Environmental justice: A criminological perspective. Environmental Research Letters, 10(8), 1-6.

Montgomery, I. (2015). Maximising production and biodiversity in NI agriculture. Belfast. http://www.niass embly.gov.uk/globalassets/documents/raise/knowledge_exchange/briefing_papers/series5/montgomery -briefing.pdf.

nidirect. n.d. Commenting on planning appeals. Retrieved April 26, 2019, from https://www.nidirect.gov.uk/ articles/commenting-on-planning-appeals.

Northern Ireland Assembly. (2016). Comparison of the planning systems in the four UK countries. Available at https://researchbriefings.parliament.uk/ResearchBriefing/Summary/CBP-7459\#fullreport.

Northern Ireland Fresh Water Taskforce. (2018). Environmental audit committee: Nitrates inquiry. Belfast. https://www.nienvironmentlink.org/cmsfiles/NIEL-FWTF-Nitrates-Inquiry-Response.pdf.

Nussbaum, M. (1997). Capabilities and human rights. Fordham Law Review, 66(2), 273-300.

Nussbaum, M. (2001). Women and human development: The capabilities approach. Cambridge: Cambridge University Press.

Planning Act (Northern Ireland) 2011. c. 25. Retrieved January 6, 2020, from http://www.legislation.gov.uk/ nia/2011/25/contents.

Ponette-Gonzalez, A. G., \& Fry, M. (2010). Pig pandemic: industrial hog farming in eastern Mexico. Land Use Policy, 27(11), 7-10. 
Pulido, L. (1996). Environmentalism and social justice: Two chicano struggles in the southwest. Tucson, AZ: University of Arizona Press.

Schlosberg, D. (2004). Reconceiving environmental justice: Global movements and political theories. Environmental Politics, 13(3), 517-540.

Schlosberg, D. (2007). Defining environmental justice: Theories, movements, and nature. New York: Oxford University Press.

Schlosberg, D. (2014). Ecological justice for the anthropocene. In M. Wissenburg \& D. Schlosberg (Eds.), Political animals and animal politics (pp. 75-89). London: Palgrave Macmillan Limited.

Schnaiberg, A. (1980). The environment, from surplus to scarcity. Oxford: Oxford University Press.

Schraufnagel, D. E., Balmes, J. R., Cowl, C. T., De Matteis, S., Jung, S.-H., Mortimer, K., et al. (2019). Air pollution and noncommunicable diseases. A review by the forum of international respiratory societies' environmental committee, part 1: The damaging effects of air pollution. Chest, 155(2), 409-416.

Sen, A. (1999). Development as freedom. New York: Knopf.

Sikor, T., \& Newell, P. (2014). Globalizing environmental justice? Geoforum, 54, 151-157.

Smith, N. (1990). Uneven development: Nature, capital, and the production of space. Athens, GA: University of Georgia Press.

Stoddard, E. (2015). Neoliberal governance and environmental risk. 'Normal Accidents' in North Carolina's hog industry. In J. Emel \& H. Neo (Eds.), Political ecologies of meat (pp. 137-157). New York: Routledge.

Stretesky, P. (2003). The distribution of air lead levels across U.S. counties: Implications for the production of racial inequality. Sociological Spectrum, 23(1), 91-118.

Stretesky, P., \& Lynch, M. (1998). Corporate environmental violence and racism. Crime, Law and Social Change, 30(2), 163-184.

Stretesky, P., \& Lynch, M. (2002). Environmental hazards and school segregation in Hillsborough County, Florida, 1987-1999. The Sociological Quarterly, 43(4), 553-573.

Swyngedouw, E. (2001). Scaled geographies nature, place, and the politics of scale. In E. Sheppard \& R. B. Mcmaster (Eds.), Scale and geographic inquiry: Nature, society, and method (pp. 129-154). Hoboken, NJ: Wiley.

The Bureau of Investigative Journalism. (2017). Intensive farming in the UK, by numbers. Retrieved April 15, 2019, from https:/www.thebureauinvestigates.com/stories/2017-07-17/intensive-numbers-of-intensivefarming.

The Bureau of Investigative Journalism. (2019). Deadly gas: Cutting farm emissions in half could save 3,000 lives a year. Retrieved June 19, 2019, from https://www.thebureauinvestigates.com/stories/2019-06-13/ deadly-gas-ammonia-cutting-farm-emissions-could-save-3000-lives-a-year.

Tomlinson, I. (2013). Doubling food production to feed the 9 billion: A critical perspective on a key discourse of food security in the UK. Journal of Rural Studies, 29, 81-90.

Walker, G. (2012). Environmental justice: Concepts, evidence and politics. Abingdon, Oxon, UK: Routledge.

Walker, G., \& Bulkeley, H. (2006). Geographies of environmental justice. Geoforum, 37(5), 655-659.

Walters, R. (2013). Air crimes and atmospheric justice. In N. South \& A. Brisman (Eds.), Routledge international handbook of green criminology (pp. 134-149). Abingdon, Oxon, UK: Routledge.

Welch, C., Marschan-Piekkari, R., Penttinen, H., \& Tahvanainen, M. (2002). Corporate elites as informants in qualitative international business research. International Business Review, 11(1), 611-628.

White. (2003). Environmental issues and the criminological imagination. Theoretical Criminology, 7(4), 483-506.

White. (2008). Crimes against nature. Environmental criminology and ecological justice. Cullompton, Devon, UK: Willan Publishing.

White, R. (2014). Eco-justice and problem-solving approaches to environmental crime and victimisation. In T. Spapens, R. White, \& M. Kluin (Eds.), Environmental crime and its victims: Perspectives within green criminology (pp. 87-101). London: Ashgate Publishing Limited.

Wing, S., \& Wolf, S. (2000). Intensive livestock operations, health, and quality of life among eastern North Carolina residents. Environmental Health Perspectives, 108(3), 233-238.

Wyatt, T. (2014). Non-human animal abuse and wildlife trade: Harm in the fur and falcon trades. Society \& Animals, 22(2), 194-210.

Young, I. (1990). Justice and the politics of difference. Princeton, NJ: Princeton University Press.

Publisher's Note Springer Nature remains neutral with regard to jurisdictional claims in published maps and institutional affiliations. 